\title{
THE EMANCIPATION OF THE OPIUM CULTIVATORS IN BENARES
}

When Warren Hastings established the English East India Company's opium monopoly in Bihar in 1773 , the contractors who undertook its management were expressly forbidden to compel the ryots (tenantcultivators) to grow poppy. Later, Warren Hastings allowed this restriction to be quietly dropped from the contracts, and in the $1780^{\circ} \mathrm{s}$ the ryots were protected only by implication, in that the contractors were required to deliver to the Company as much opium as could be procured "lawfully and reasonably". Although no legal powers of coercion were granted, it accorded well with native custom that the ryots should be compelled to keep up the cultivation where it had previously existed, and when Lord Cornwallis investigated the matter in 1788 he found it to be generally understood that such compulsion was in force. Cornwallis intended to bring to the Company's territories the benefits of personal freedom under the rule of law, but he did not wish to disrupt the opium arrangements. He therefore laid down fixed scales of remuneration for the opium ryots which he hoped would be generous enough to make them willing to continue and extend the cultivation, but did not immediately proclaim their emancipation. The contracts of 1789 were ambiguous; they did not say whether the continuance of existing cultivation was to be compulsory, but only that its extension was to be left to the option of the ryots. In 1793 , however, when the ryots had had time to experience the benefits of the fixed rates of pay and their deliveries were increasing satisfactorily, the cultivation was declared to be completely optional. This caused no difficulties in Bihar. ${ }^{1}$

The Company established an opium monopoly in Benares in 1786 , and met some opposition from both ryots and zamindars (superior land-holders). The Resident tried to introduce poppy in districts 1 India Office, London, Bengal Revenue Consultations 23 Nov. 1773, 5 June 1781, x6 Sept. 1789, and 26 Apr. 1793 (Salt \& Opium). 
where it had not been usual. The management of the monopoly was given to an experienced Indian, and the revenue officers were ordered to help him in causing suitable land to be prepared and reserved for poppies, with the consent and good will of the ryots. Zamindars were threatened with punishment if they interfered. ${ }^{1}$ According to a European merchant who was present at the time and who seems a reliable witness,

"The ryots, from the influence and insinuations of the zemindars, who wished not to see the cultivation of this article prosper, from the apprehension of a new authority being introduced amongst them, were purposely inattentive and neglectful in extracting the opium from the poppy at the proper periods; and as a plea for this conduct represented that they were unacquainted with that art, and of making the proper incisions therein. Ramchand Pundit informed the Resident of this circumstance and produced a quantity of the poppies which the ryots had allowed to get quite ripe without taking the opium therefrom. From this however they experienced no loss, as they could always find a ready sale for the shells thereof, since the opium had not been extracted from them and therefore those who habituated themselves to the use of this article consumed these instead of the prepared material and readily gave a good price for the same - besides that the ryots could sell the seed separately... No doubt but the ryots in those districts where the introduction of this cultivation was a new measure were more particularly inimical thereto from the consideration that the opium was a monopoly in the hands of Government, and that if they engaged therein they would be subjected to many risks and to the labour of learning an art they were little if at all acquainted with."

The ryots were evidently persuaded under pressure to propitiate the authorities by sowing poppies, but neglected to water them, and if the crop survived this neglect did not harvest the opium properly. It was not easy to coerce the inhabitants of these districts, since their "violent and obstinate temper" expressed itself in the embarrassing practice of protesting against superior authority "by violent acts even against their own persons."

In the season $1788-9$, Duncan, the Resident, reformed the method of calculating the payment due to the ryots in such a way as to increase the effective price received by them, in order to encourage them to cultivate freely, "without any apprehension of coercive measures".

1 Bengal Board of Revenue Proceedings, 18 June 1789.

2 Rev. Cons. 9 Sept. 1789 . 
After the lands had been planted, however, fears of food shortage arose and Duncan permitted the ryots if they thought it necessary to abandon the opium cultivation they had engaged for, in order to grow barley and wheat. Duncan declared that he could have procured the full quantity engaged for, but had refrained when conditions proved adverse. ${ }^{1}$

In 1789 , a four-year contract for the procurement of Benares opium was granted to Williams, the surgeon there. He was placed in some difficulty by a delay on the part of the Bengal authorities in sanctioning the necessary advances to him, and because, as Duncan explained, "the ryots, from their last year's experience of the precariousness of the culture, will I imagine be rather indisposed to extend it where it has not hitherto usually been."2 In October, Williams asked for parwanas (written orders) to the zamindars and amils (Indian revenue officers) "that it will be expected that they will cause to be cultivated and sown with poppy seeds as much ground this year as the last and that the Contractor will issue the advances to the ryots so soon as he receives cash from the Treasury for that purpose". He was informed that in July the Resident had issued the usual parwana to promote the preparation and reservation of land for poppies "as far as possible" and "with the consent" of the ryots. The cash became available on 5 November. On the 13 th, Duncan informed Williams that two ryots had complained of having had advances forced on them by gumashtas (Indian agents), who had required them to plough up some barley to make room for poppies. He asked Williams to prevent his agents from proceeding to such extremities. A petition from other ryots, however, soon arrived. They declared that they had waited as long as they could for advances, but:

"No gomastah [gumashta] was ready to make them. At last we got seeds from a merchant on credit to pay interest and sowed them for the rubby ${ }^{3}$ crops which are daily growing. In the meantime a gomastah on the part of Dewan Dalah Ram, who carries on the opium business for Dr. Williams, came here and oppresses, saying, 'Cut what barley there is and plant the poppy in its stead.' My protector, the case is that the time is now past for sowing the poppy, and if we were now to plant it, it would not grow, besides which we borrowed from merchants, which would all be lost, neither would the revenues be received, besides which we live upon the product of our ground. Now owing to this oppression, what shall we do? You are the master, what is just to us order."

1 Rev. Cons., 21 Jan. \& 2 Sept. 1789.

2 Rev. Cons. 2 Sept. 1789.

${ }^{3}$ Rabi : crops for the spring harvest. 
Other petitions to the same effect flowed in, and:

"The Resident ordered on all of them that when grain was actually sown and growing it should not be cut up to make room for the poppy, but that wherever Mr. Williams or his agent found land unoccupied by grain they might oblige the ryots (being such persons who had last year cultivated this article) to sow the poppy seed in such ground."

Williams, meanwhile, had been trying to get a list of the ryots who had grown opium in the previous season. The amil of Ghazipur, the only district in Benares where opium cultivation had been long established, was unhelpful. It was the responsibility, he said, of the opium managers to keep such records. He could procure the information from the village accountants, but "examining the separate papers of each village will take up a long time, and the opium planters, when they hear that advances will be made them, will of their own accord attend to receive them". Duncan, however, issued a parwana requiring the amils to supply the information for their districts, and ruled:

"Whereas it hath at this time appeared from the representation of Mr. Williams that the kwyries [i.e. the caste to which most of the opium cultivators belonged] are negligent and inattentive in respect to taking advances for and cultivating the poppy: it is necessary that those ryots who had last year cultivated the poppy do also this year take advances and carry on the cultivation."

Williams was not satisfied. He argued that the terms of his contract implied a power of coercion to keep up the cultivation of past years and asked what would be done to enforce this in the ensuing year. Duncan refused to give a ruling and referred the matter to the Bengal government. The Governor-General in Council replied by approving Duncan's proceedings without comment. Thus the use of the amils' authority to assist the contractor in keeping up the cultivation was tacitly approved. ${ }^{1}$

Despite all difficulties, Williams was able to fulfil his contract in the first year and to deliver an increasing surplus to the Company each year afterwards. His efforts, however, involved him in further disputes about the degree of coercion permissible, and provoked resistance from the ryots. ${ }^{2}$

Of the ryots of Jaunpur, a district where opium had not been grown before 1786 , Duncan reported in 1791 :

1 Rev. Cons. 9 Dec. 1789.

2 Rev. Cons. (S. \& O.) I July, 26 Aug. \& 25 Sept. $179 x$. 
"Their being at all induced last year to try to begin to raise the poppy in a few begahs ${ }^{1}$ by way of experiment was effected only through the countenance of and some degree of extraordinary exertion on the part of the Residency and of those local officers of the revenue dependent on it, in co-operation with the contractor, but I have still reason to believe that the ryots there are strongly inclined to resist to the utmost the permanent introduction and establishment of the cultivation of opium into their part of the country, and their opposition for some time in respect to forming the estimate of the little they raised (the whole not exceeding 200 begahs) proceeded I believe much more from their great general aversion to the experiment and their wish that it should fail, than from any desire to smuggle an article which on a former attempt made three years ago was found equally impracticable in their part of the country, and which they do in fact appear averse to follow; nor can they (I have reason to imagine) undertake such culture without suffering an unavoidable loss from the difference between the established rates of the rent of their lands and the prescribed prices for opium to be paid to them by the contractor; and if I find this assertion on their part (which is now ascertaining) to be well founded, the Board will, I think, expect that I shall put an end to engaging or making them receive advances."

Williams agreed that these ryots had deliberately spoiled the poppies as a means of expressing a disinclination to cultivate, but asserted that it was due to the influence of an "incendiary" headman, and hoped to overcome it by a demonstration of the profitability of opium on experimental plots worked by a few experienced cultivators who had been introduced to the district. According to Williams, ryots of neighbouring districts, who were willing to cultivate, were hesitantly awaiting the outcome, fearing that if they grew opium while Jaunpur was exempt they would be persecuted by their fraternity. Evidently the caste organisation of the koeris, a humble community which specialised in growing vegetables, was capable of acting as a kind of trade union. That some cultivators should have excused themselves to the contractor by saying they were afraid to go against their fraternity does not, of course, necessarily indicate their true feelings.

The trouble in the old opium districts began in December $179^{\circ}$. Petitions were received at the Residency from ryots in a number of villages in one district who alleged that they had been forced to take

1 A bigha was about half an acre. 
advances for more land than they had planted with poppy in previous years, and that these engagements had been enforced by the forcible ploughing up of tobacco and other crops to make room for poppies. The zamindars supported these petitions and said that the ryots were threatening to abscond if justice were not done, in which case the land would be uncultivated and the land-revenue could not be realised. The complainants were aware of their obligation to keep up the previous poppy-cultivation and of the Resident's orders for the encouragement of increased production. They said that they had been willing to engage for a moderate extension, but that the demands of the gumashta had been unreasonable. Their representations were formulated in a uniform manner, but with variations in the description of the coercion used against them. They had been summoned to the opium factory before the season for sowing. One party claimed to have been confined for a day by the contractor's servants who "the whole of it would not suffer us to make water or go to stool", as the translator expressed it. When "their lives were at their lips, helpless", these ryots took their advances on the terms dictated to them. Another group complained, "they placed us on the top of the house, and committed many severities on us". When the ryots had failed to comply with their engagements and their tobacco had been forcibly ploughed up, in some cases the poppy had been sown in its place by the contractor's people. In other cases the ryots had sown it themselves, but said that they had been coerced by blows with sticks or slippers, or by threats ("We will enjoy your mother, wife and your daughter."). In one case, "To such a length did they carry their tyranny that they stopped a corpse and would not suffer it to be burnt; as we were helpless, we sowed the poppy".

The Assistant Resident dealt with these complaints by a parwana to the amil to prevent further ploughing up of tobacco crops before they were ripe, but tried to avoid any damage to the contractor's authority by adding that the contractor might certainly increase the poppy cultivation where nothing else had been sown and that the amil should assist him. The amil, in reply, took credit for having caused the increase in poppy-sowings which had already taken place, but stated that no more uncultivated land was available, that it was now too late to sow poppy with any hope of its maturing, and that if tobacco might not be ploughed up, extra room for poppies could be made only by ploughing up turnips and other vegetables. This evoked a peremptory parwana from Duncan that no standing crops must be dug up. The ryots were much heartened by this, and, according to the contractor's gumashta, stopped watering and weeding their poppies and did not come to the factory for the further advances due to them. 
Duncan had consequently to issue a parwana that they must continue to fulfil their obligations. However, he ordered an assessment of the damages they had suffered by the destruction of their crops, and eventually compelled Williams to pay them compensation to the amount of 65 Rs. in all.

Duncan's investigation did not, of course, show conclusively whether the ryots had been compelled to take the initial advances. He considered that if the ryots had entered the engagements willingly they would probably have complied with them by sowing the required amount of land. The amil hinted that the contractor had acted unreasonably by requiring an extension of cultivation without enquiring into the capacity of the ryots to comply. Poppy required a great deal of labour and water which the ryot might not be able to provide, and the ryots, despite their advances, needed other crops to support their families until the opium was delivered and their accounts were settled.

When the complaints had come in, Williams had at first supported his gumashta, pointing out the need to compel the ryots to fulfil their engagements, and had seemed to Duncan to admit having authorised the destruction of the tobacco crops. When Duncan made his own attitude clear, however, Williams shifted his ground and asserted that the gumashta had exceeded his instructions. Afterwards, Williams seems to have given up this means of enforcement. Instead, he asked for heavier legal penalties. The only relief he could get from the courts under the existing regulations was to recover from the ryots, with $12 \%$ interest, the advances for the land which had not been put under poppies, but this "instead of a punishment would become a convenience, as they cannot borrow money among themselves on such easy terms". The government, probably because of doubts about the voluntariness of the engagements, did not take any action, beyond remarking that the contractor could sue in the courts for damages as well as for the return of his advances. In 1 799, when the government procured opium through its own agents, it was found necessary to impose the penalty that the ryot must repay threefold the advances for any land which he did not cultivate according to his engagement. ${ }^{1}$

Duncan's parwana against the ploughing up of other crops to make room for poppies brought to light another dispute. The ryots of a different district heard of it, and petitioned for compensation for vegetables which had been sown intermingled with the poppies and which had been uprooted at Williams' order. They also resisted further uprooting and threatened not to grow poppies in future. It was the custom to plant with the poppies quick-growing vegetables such as

${ }^{1}$ Reg. VI of 1799. 
radishes or carrots which ripened and could be removed before the poppies matured. Williams considered that this diminished the yield of opium and infringed his rights, and he had accordingly inserted a rather ambiguous clause in the ryots' engagements for $1790 / 1$ : "We will not sow anything whatever among the poppies, and if any quiries should sow any vegetables... we will at the time of weeding extract them and sell them in the Bazaar and will not make any complaint on that head". The ryots, of course, followed their custom and not their engagement. At the beginning of December, however, Williams was in the district and ordered the removal of the vegetables. It is not clear whether this was done by his servants, as the ryots alleged, or, as Williams said, by the ryots themselves at his requisition. He claimed to have convinced them by reasoning of the advantage to themselves of the higher yield of opium they would obtain. The amil testified that it was customary to remove the vegetables after a month or six weeks, and on this Williams claimed that he had merely fulfilled the custom by insisting on removal at the proper time. The ryots, however, denied that the vegetables had all been ripe, and said that they had been compelled to uproot too many at once, and at too short notice, so that they could neither eat them all, nor dispose of them in the market, nor give them to their money-lenders. Duncan tried to investigate the facts in February $179 \mathrm{I}$, in order to assess any compensation that might be due to the ryots, but gave up after a remonstrance from Williams that it would engender dissension and further petitioning, and probably induce the ryots to leave their fields at the critical time of the opium harvest. Williams protested that the award of even a single anna in compensation would destroy his authority and cause "the spirit of representation" to infest other districts.

The aggrieved ryots were meanwhile refusing to enter final engagements for the amounts assessed by the usual survey of the ripening crops. It is not clear whether, as was alleged, they resisted the assessment or merely asserted that it was unfair. They offered an oath on Ganges water that they would deliver their whole produce, but asserted that the gumashtas were procuring unfair assessments in revenge for the complaints about the vegetables. This resistance was overcome by a parwana from Duncan, and deliveries proceeded, though not without recrimination. The matter was not finally settled until June, when Duncan persuaded the ryots to abandon their complaints in return for a promise from Williams to respect their custom in future. Williams alleged, however, that part of the trouble had arisen from the ryots' sowing plants of slower growth amongst the poppies, contrary to custom. 
Duncan considered that the engagements taken from the ryots to grow only poppy on the lands engaged for were invalid. He argued that the regulations which fixed the prices payable to the ryots assumed the continuance of existing customs, and that if the customs were altered to the disadvantage of the ryots the prices would have to be proportionately increased. The ryots themselves denied that they had consented to these engagements. The documents had been signed by chief cultivators on behalf of the rest, and the ryots argued that these headmen were servants of the contractor, who had acted in concert with the gumashtas "to plunder and ruin us". Williams asserted that the headmen were appointed by the general consent of the ryots and that one of them, a notorious opium smuggler, had been the agitator responsible for all the trouble. It was true that some of the headmen were subservient to Williams and willing to sign statements of the perfect contentment of the ryots, that some were leaders of the opposition against him, of whom one appears to have threatened to go on hunger strike, and that others would sign statements for either party as required. Williams' gumashtas protested that they could not enter into direct dealings with each several ryot, that in the negotiation of engagements, the distribution of advances, the assessment of the crops and the settlement of accounts they had always dealt with the headmen, and that therefore the ryots were bound by the engagements made by the headmen on their behalf, according to the ancient procedure.

The custom of planting vegetables amongst the poppies prevailed also in Bihar, and the contractor there complained of it in $179 \mathrm{r}$. The government considered that it would be "cruel, impolitic and injurious" to prohibit the practice. For one thing, poppies were greatly liable to damage by hail, and the interplanting of vegetables gave the ryots some insurance against this risk. Since the practice was customary it must be assumed that the ryots' engagements permitted it, unless the contrary was specified. If the contractor could compensate the ryots for the loss of the privilege, they might perhaps agree to give it up. In that case, the contractor could appeal to the courts if the ryots infringed such agreements. If the Bihar contractor had chosen to follow this advice, no doubt he would have run into troubles similar to those in Benares. ${ }^{1}$

Williams asserted that his difficulties were due to the novelty of the contract system in Benares, where the ryots had never before been "under proper control". Duncan believed that Williams' infringement of custom and the bullying ways of his servants had roused the resistance of the ryots, so that they contested every point, complained without cause of false weighing, and diluted their opium with water. It

${ }^{1}$ Board of Rev. Proc. s Sept., 3 Oct. \& 19 Dec. 179 I. 
would therefore be to Williams' interest to conciliate the ryots. Williams appears to have taken this advice, and in the remaining years of his contract, according to the Assistant Resident, he kept the ryots happy, with the help of the revenue officers. Perhaps the change was due largely to Williams' dismissal of his Indian manager, whom he accused of embezzling opium and who in turn accused him of adulterating the opium and cheating the ryots by false weights. Some of the gumashtas were involved in the quarrel, and probably Williams was able to keep his servants in better control afterwards. ${ }^{1}$

Nevertheless, Williams still wanted coercion. He asked, unsuccessfully, that the government should lay down penalties for ryots who refused to keep up the previous cultivation. He interpreted the regulations of 1789 as implying that any extra cultivation voluntarily undertaken in one year should be compulsory afterwards, and said that he had relied on this in making his bid for the contract. Duncan dissented from this, but parwanas were issued from the Residency to the amils in 1792 and 1793 which not only ordered them to keep up the previous cultivation, but also:

"In places where last year no poppy was cultivated, you must cause each person to cultivate according to his ability. Whatever increase there is in the cultivation of the poppy will add to the amil's good name."

Another translation of the parwana, however, read "In such places as there have been no opium planted last year, everyone may according to his ability commence the poppy cultivation..."2

In 1793 , when Williams made an unsuccessful bid for the new contract, he offered to contract for a specific quantity of opium only if the clause emancipating the ryots were removed from the new regulations. He observed:

"that the claim he has heretofore had on the opium ryots deterred the amils and other officers of the revenue from interfering with them, and that it is to the protection he afforded them by his representations to the Resident etc. against the rapacity and oppression of these people that he owes his success in the increase of cultivation; but he has reason to apprehend from the opposition which he has invariably met with in the amils and their subordinates that on the contractor's being deprived of this claim, they will by every means in their power prevent the ryots from cultivating the poppy in order to get rid of the interference of the

${ }^{1}$ Rev. Cons. 26 Apr. \& 29 Nov. 1793.

${ }^{2}$ Rev. Cons. 7 March 1794 , nrs. 47 \& 54. 
contractor between them and the ryots, and that it is probable most of the amils will force them to take advances for the cultivation of sugar either for themselves or others, which may turn out much more advantageous to the amils and fully as much so to the ryots, whilst the contractor being limited in price and without any authority or control over either amils or ryots is liable to be subject to a penalty to Government on short delivery, without any resource whatever."1

The new contractors, Gilchrist and Charters, declared that their local knowledge enabled them to hazard the "new conciliatory plan" for voluntary cultivation on the lowest possible terms, but that the general opinion "in the highest circles at Benares" was that no contractor could fulfil his engagements "unless armed as usual with compulsive powers". ${ }^{2}$

The danger which Williams had foreseen was greater from indigo than from sugar. The master-manufacturers of indigo were Europeans, and when their wishes were supported by the zamindars and amils it might be hard for the ryots to refuse advances for indigo cultivation. The agent for the Bihar contractor was already complaining in 1794 :

"From the great number of indigo establishments now forming in Behar, and the undue influence which Europeans thus settled in different parts of the districts use to induce the ryots to receive advances for the cultivation of indigo, the opium cultivation is likely to suffer a material diminution unless immediate and positive measures are adopted by Government to protect the opium ryots first from having indigo advances forced upon them and next in protecting them in possession of their lands, which the indigo settlers find means to deprive them of through a native agent or gomastah in whose name they rent the villages and either compel the ryots to cultivate indigo or dispossess them of their lands entirely. Complaints of this nature have reached me from different places where indigo establishments are, and the landholder being thus in the interest of the indigo-planter or in fact subservient to his will, it is difficult if not impossible for the ryot to obtain redress, nor am I sufficiently acquaint with the Judicial Regulations to know whether in such a case they would afford any. This makes me anxious it should be submitted to Government without delay, particularly as the opium lands of

\footnotetext{
1 Rev. Cons. (S. \& O.) I I June 1793.
}

${ }^{2}$ Rev. Cons. 7 March 1794 no. 47. 
many villages thus held at the will of the indigo settlers are either preparing for or occupied with indigo."1

Thus the power of the zamindars, which had been increased by the failure of Cornwallis to define the rights of the ryots in his arrangements for the Permanent Settlement of the land-revenue, was being exercised for the benefit of the indigo masters. The insecurity of the ryots' land rights was not as yet a general cause of oppression, because there was still a shortage of cultivators for the available land, so that the tenant's occupancy was not likely to be disturbed in practice. It was a different matter when the land was wanted for indigo, and a test case arose in Benares in the autumn of $1793 .{ }^{2}$

Scott, a free merchant of Benares, leased the lands of a certain village for indigo cultivation, from the zamindar, who held them from the government under a Decennial Settlement which had not yet been made permanent. The ryots, who had previously grown some opium, though the amount was disputed, objected. The zamindar claimed that they were in arrear with their rents. The ryots alleged that the zamindar was demanding more than he was entitled to. The zamindar denied that the ryots had any permanent, hereditable rights in the land; the ryots declared that they were the descendants of the original settlers in the village, that the permanent interest in the land was theirs, and that the zamindar had merely the rights of an incumbent. Cornwallis had tried to clear up confusion of this kind by requiring the zamindars to grant decennial leases which defined the position of each ryot.

The Acting Resident in Benares, Treves, appeared to favour Scott, and instructed the amil of the district to investigate and decide the case, adding that if the facts were as stated by the zamindar, he, having been settled in possession of the land for ten years by the government, was the master. The ryots appealed to the opium contractors, saying

"We don't prevent the sowing of indigo, but agreeably to the Resident's orders that no-one by force shall take away another's land, therefore our cultivation which we have had for many years we will not give up to anyone to cultivate indigo in... We will go in thousands to Calcutta, as we belong to the opium kooty [factory] and are not without a protector."

The amil, between these contending influences, procrastinated and drew on himself a rebuke from Treves that since the zamindar had an

1 Rev. Cons. (S. \& O.) 28 July 1794.

${ }^{2}$ Rev. Cons. 7 March 1794. 
absolute right during the Decennial Settlement, it was very extraordinary that the matter could not be decided. Scott became impatient, and sent a numerous party under a European servant to plough up the disputed lands and sow indigo. The ryots resisted and their ringleaders were seized. While the captives were being taken to Scott, in order that he might decide what to do with them, they were rescued after a brief scuffle by servants of the opium factory. Scott's people, however, were able to proceed with the planting of indigo, and when some of the plants were destroyed by the ryots, they re-planted. Scott declared this to be the second occasion on which his indigo had been ploughed up by the orders of Gilchrist and Charters, or of their agents.

Gilchrist complained that the news of these events was making the ryots everywhere hesitate to take opium advances. They did not wish to do so, if opium ryots could be "beat, imprisoned and dispossessed by every amil and zemindar who thought proper to do so in defiance of standing regulations", and forced to weed Mr. Scott's indigo fields.

Gilchrist had already had similar troubles in the saltpetre business. His advances for saltpetre had been obstructed by the amil in a certain district, for the benefit of an Indian merchant who, he believed, had an effective monopoly of the business. Gilchrist had been accused of seducing his rival's suppliers from their engagements and of giving advances by compulsion, and Treves had issued parwanas against Gilchrist in the belief that the Indian was being driven out of business by unfair practices, as had so often happened in the past. Gilchrist's suppliers accordingly told his agents:

" 'Why! this tremendous man Baboo Ram Narain produces perwannahs by the score in his own favour, while you have not to this day shown us one in this quarter which Ahlad Mishr [the amil] cares a fig about. Then how will our feeble voice reach the Hoozoor [the Presence of Authority], while we remain under an amil the friend of our master's adversary?' In short, they have plainly told our gomastahs, 'Get an order soon, or we must change sides to save our bacon'."

Similarly in the present case:

"When a kwyrie is requested by us to plant 3 or 4 begahs with poppy, his answer is, 'With all my heart, provided you will not allow anybody to expel me from the 6 or 7 other begahs which I cultivate with grain for the subsistence of myself and family etc.' We in general reply that as the opium contractors we shall certainly state their case to the Resident... and make little doubt of their getting justice done them... since a just government will 
naturally protect in their rights a class of poor natives from whom so large a revenue is produced for the Company."

That is to say, the ryots would voluntarily take advances not so much for the money, but for protection, and were awaiting the outcome of Gilchrist's struggle with Scott to see whether this protection would be worth having.

Gilchrist and Charters asked the Governor-General in Council to recognise them as the protectors of the opium ryots, protesting that their only aim was to break "that invisible rod of undue influence which, in spite of all Your Lordship's efforts, continues to crush the rising prosperity of India". They also asked for a parwana to the effect that poppy cultivation was still pleasing to the government, and complained at Treves' refusal to issue one:

"We never conceived it could be the duty of any public officer to sedulously prevent the conciliatory plan for cultivating the poppy succeeding by constantly exposing the Contractors' want of coercive powers, on the contrary we fondly hoped he would patiently wait till some kwyrie or other complained of our coercion, otherwise no consideration on earth could have induced us to meddle with the opium investment at all."

The government ordered that the lands should be restored to the ryots, and that the zamindar must seek the recovery of any arrears of rent by proceeding against the ryots in the courts. The desire of the government for the encouragement by the zamindars of voluntary opium cultivation was to be made known. Europeans were in future not to be allowed to buy or rent more than so bighas of land in Benares, and were not to take up any land at all except for the erection of buildings, with the special permission of the government in each case. Thus the plantation system towards which Scott's activity appeared to be tending was checked, and indigo was to be procured in future only by the traditional method of advances to individual peasant cultivators.

There was some delay in the reinstatement of the aggrieved opium ryots, who were afraid to plough up the growing indigo plants owing to threats that Scott could claim compensation, but they did it as soon as the government's intention was made plain. The amil, now that he knew which way the wind was blowing, decided in favour of the ryots. The "conciliatory system" of Gilchrist and Charters could now succeed in Benares, and they were able to obtain increasing deliveries during the period of their contract.

Gilchrist and Charters were told that they could not be given any 
special powers to protect their opium ryots in matters of land-revenue, because the Benares opium revenue was of little importance in the eyes of the government in comparison with the principle of strict and impartial enforcement of the law in all cases affecting property. They were also forbidden to give badges to their servants. Duncan had approved such badges, for the identification of those who had authority to make advances and investigate complaints. This had been conditional on the badges being of such design that they could not be confused with those of government peons, and on a written undertaking by the contractors that the badges would only be used for opium business. The government considered that in practice such badges would always be taken as a sign of public authority over the amils and ryots.

The opium troubles in Benares were settled by administrative action, not by due process of law, but the government's decision was a step in the direction of Cornwallis's ideal of freedom under the law. His policy of making opium cultivation voluntary by guaranteeing a satisfactory price to the ryots was succeeding; but in the early I 790's, for the better establishment of the cultivation in Benares, he had permitted an overtly coercive support of the contractor by the revenue officers. Thus the desire for reform had been sacrificed for a time to the material interests of the Company. 